\title{
MACROMYCETES INDICATOR SPECIES FOR XEROTHERMIC GRASSLANDS OF THE CHĘCINY DISTRICT
}

\author{
${ }^{1}$ Justyna Jaworska, ${ }^{2}$ Janusz Łuszczyński, ${ }^{2}$ Bożena Kuszczyńska, ${ }^{3}$ Agnieszka Tomaszewska
Department of Botany, Institute of Biology, Jan Kochanowski University, Świętokrzyska 15, 25-406 Kielce, Poland e-mail: 1j.jaworska.kielce@gmail.com, ${ }^{2}$ jluszcz@ujk.kielce.pl, ${ }^{3}$ sikorka105@wp.pl

Received: 07.10.2011

\begin{abstract}
In the Chęciny district, xerothermic grasslands developed on deforested slopes of limestone hills, truncated folds, and mounds. Their origin is directly connected with agricultural and pastoral farming of man. Xerothermic grassland belongs to the class Festuco-Brometea, and the alliance Cirsio-Brachypodion. The plant association Thalictro-Salvietum pratensis is the most widespread in this area. The xerothermic grasslands have their own characteristic biota of macromycetes. The following steppe, xerothermic, and thermophilous fungi deserve special attention: Agaricus bernardii, Camarophyllus virgineus, Conocybe sienophylla, Entoloma incanum, Hygrocybe konradii, H. persistens, H. reae, Lepiota alba, and Leucopaxillus lepistoides.

As a result of the xerothermic swards being progressively overgrown by shrubs and trees, among others, by Pinus sylvestris, one can find fungi species accompanying this tree: Suillus collinitus, also fungi producing underground fruit bodices $R h i$ zopogon obtextus and Rh. roseolus. The main factors threatening xerothermic grasslands of the Chęciny district are, among others, the devastation and disappearance of natural habitats, often as a result of inappropriate human land management as well as the pollution of air, water, and soil. The effective protection of rare, threatened, and also legally protected fungi species is only possible by protecting their natural habitats as a whole.
\end{abstract}

Key words: xerothermic grasses, macromycetes, Festuco-Brometea, Cirsio-Brachypodion, steppe fungi, thermophilous fungi.

\section{INTRODUCTION}

The Chęciny district can be characterized by the presence of limestone hills, truncated folds, and single mounds. Xerothermic grasslands developed on deforested slopes of these hills. The development of xerothermic grasslands was strictly connected with human agro-pastoral activities. Xerothermic swards usually occupy small areas, but one can find there many rare and interesting plant species, such as: Cerasus fruticosa, Thymus marschallianus, Inula ensifolia, Cirsium pannonicum, Pulsatilla vernalis, and Aster amellus. These grasses belong to the class Festuco-Brometea and the alliance Cirsio-Brachypodion. Investigations included the areas where the following xerothermic grassland associations, belonging to the above mentioned class, were distinguished: Thalictro-Salvietum pratensis, Inuletum ensifoliae, and Origano-Brachypodietum. The achieved results have a significant importance for the identification of macromycetes biota growing in rare and dying ecosystems in the communities belonging to the class Festuco-Brometea within the investigated area.

The importance of this problem stems from the fact that knowledge and literature on fungi associated with thermophilous and xerothermic grasslands in $\mathrm{Eu}-$ rope and Poland are still very inadequate ( $\breve{\mathrm{S}} \mathrm{m}$ a r d a , 1957; Wojewoda, 1974, 1975; Skirgiełło, 1976; Winterhoff, Hinkova and Stoičev 1983; 1985, 1995; Li z oň, 1995; B u jaki e w i c z, 1997; Krieglsteiner, 1999 a, b; Jordal, 2002; Dahlberg and Croneborg, 2003; New ton, et al. 2003; Ławrynowicz et al. 2004; Sta sińska, 2002, 2008; S tas ińska and Praj s, 2002; Łuszczyński, 2007; Senn-Irlet, et al. 2007; Łuszczyński and Łuszczyńs ka, 2009, 2010).

In recent years, many changes in the xerothermic grassland communities of the Chęciny district have been observed. These changes can lead to the disappearance of rare plants as well as whole phytocoenoses that are extremely interesting. The factors threatening the xerothermic biocoenosis are mostly the following:

- artificial afforestation of former arable land and pastures; 
- cessation of farm animal grazing leading to the succession of associations and overgrowing of the grassland by shrubs and young trees;

- destruction of the grassland by burning (particularly in the spring), field vehicles, creating unauthorised routes for fans of motorsports, even in the protected areas;

- unregulated waste disposal.

The xerothermic grasslands have their own macromycetes biota characteristic for them. The aim of the investigations was to identify resources of macromycetes growing in the xerothermic grasslands of the study area and to distinguish indicator species for them.

\section{MATERIALS AND METHODS}

The study material comprised macromycetes fungi belonging to the classes Ascomycetes and Agaricomycetes. The investigations included observations and collection of fruit bodies in the xerothermic swards of the Chęciny district in the period 2003-2010. The study was carried out in 15 permanent plots distributed in the communities belonging to the class $\mathrm{Fe}$ stuco-Brometea. Collection of fruit bodies was carried out each year from March till November with the frequency of every two weeks. Furthermore, fungi were also collected outside the permanent study sites, using so-called the itinerary method, which allowed us to enrich our observations and to gather data concerning the composition of macromycetes species growing in the xerothermic grasslands.

To illustrate the floristic composition and existing phytosociological relationships in the investigated phytocoenoses, phytosociological relevés were performed using the B raun-B lanquet (1964) method. The nomenclature for fungi is according to $\mathrm{Woje}$ w o d a (2003), and Ch mi el (2006), vascular plants according to $\mathrm{M}$ ire $\mathrm{k}$ et al. (2002), and plant communities according to Mat u s z kie wi c z (2001).

The identification of collected material was done in two stages. In the first stage, if it was possible, fruit bodies were identified in fresh samples, while during the second stage identification was performed after fruit bodies had been dried in a laboratory oven. Microscopic observations concerning the size of spores, basidia, cystidia, and hyphae were carried out under a light microscope, whereas measurements of these elements were made using an eyepiece micrometre with an accuracy of $0.25 \mu \mathrm{m}$.

\section{RESULTS AND DISCUSSION}

During the course of the investigations on the mycobiota of the Chęciny district xerothermic grasslands, the occurrence of more than 80 species of macromycetes was confirmed. From among this group, 27 species were selected which were identified, based on their general distribution and habitat requirements, to be distinctly connected with the xerothermic grasslands. These species can be considered to be indicative of this type of habitats (Table 1).

The analysis of the macromycetes species composition of the studied grasslands belonging to the class Festuco-Brometea reveals its uniqueness. Of particular importance are the steppe, xerothermic, and thermophilous fungi whose presence underline the mycological relationship with the plant communities belonging to the alliance Cirsio-Brachypodion, and these are as follows: Conocybe sienophylla, Entoloma incanum, Hygrocybe konradii (Fig. 1), H. reae, Lepiota alba, Leucopaxillus lepistoides. Leucopaxillus lepistoides (Fig. 2) has the most outstanding features; it is considered to be a typical steppe species which occurs here on the northern boundary of its range ( $\mathrm{u} \mathrm{s} \mathrm{z} \mathrm{c} \mathrm{z} \mathrm{y} \mathrm{ń} \mathrm{s} \mathrm{k} \mathrm{i} \mathrm{,}$ 2006 ; 2010). An interesting fact is that the site of this species in Polichno remains uninterrupted since 2003 and also that it produces fruit bodies almost every year, with the exception of 2004. The occurrence of typical macromycetes steppe species is very rare in Poland. Equally interesting and rare is Conocybe sienophylla, a South European species that is associated with xerothermic grasslands (Ł u s z c z y ń s k i, 2007; 2008). Additionally, other interesting fungi connected with the Thalictro-Salvietum pratensis grassland are Agaricus bernardii (Fig. 3) and Camarophyllus virgineus.

A characteristic feature of the grassland mycobiota in this area is the occurrence of calciphilous fungi that include, among others: Entoloma incanum, Hygrocybe konradii, H. reae, Lepiota alba, Leucopaxillus lepistoides, and Conocybe sienophylla, which can be considered to be a characteristic species for the grasslands belonging to the alliance Cirsio-Brachypodion (Ł u s z c z y ń s k i , 2007).

Fruit bodies of Crinipellis scabella occur on a massive scale on dry and dying grass blades (Łuszczyński and Łuszczyńska, 2009). Fruit bodies of Marasmius oreades and Vascellum pratense also occur in vast numbers. These are fungi with a wide range of occurrence, mostly in the grasslands in question, but also in psammophilous grassland, and in dry pine forests.

Changes taking place in the plant communities have a strong influence on the species composition of fungi (S t a sińska, 2003). In connection with tree planting and due to the grasslands being progressively overgrown by shrubs and trees, among others by Pinus sylvestris, species of mycorrhiza fungi accompanying these processes were recorded such as, for example, epigeous Boletus luridus and Suillus collinitus as well as fungi producing hypogeous fruit bodies: Rhizopogon obtextus and $R h$. roseolus. 
Table 1.

List of macromycetes species associated with the Chęciny district xerothermic grasslands

\begin{tabular}{|c|c|}
\hline Species of macromycetes & $\begin{array}{l}\text { Plant association } \\
\text { in which the occurrence of macromycetes was confirmed }\end{array}$ \\
\hline Agaricus bernardii Quél. & Thalictro-Salvietum pratensis \\
\hline Agaricus romagnesii Wasser & Thalictro-Salvietum pratensis, Origano-Brachypodietum \\
\hline Agaricus xanthodermus Genev. & Thalictro-Salvietum pratensis \\
\hline Agrocybe dura (Bolton) Singer & Thalictro-Salvietum pratensis, Inuletum ensifoliae \\
\hline Agrocybe vervacti (Fr.: Fr.) Singer & Thalictro-Salvietum pratensis, Origano-Brachypodietum \\
\hline Arrhenia retiruga (Bull.) Redhead & Thalictro-Salvietum pratensis \\
\hline $\begin{array}{l}\text { Camarophyllus russocoriaceus (Berk. \& Jos. K. Mill.) } \\
\text { J. E. Lange }\end{array}$ & Thalictro-Salvietum pratensis \\
\hline Camarophyllus virgineus (Wulf.: Fr.) P. Kumm. & Thalictro-Salvietum pratensis \\
\hline Camarophyllus virgineus var. fuscescens (Bres.) M. M. Moser & Thalictro-Salvietum pratensis \\
\hline Conocybe sienophylla (Berk. \& Broome) Singer & Thalictro-Salvietum pratensis \\
\hline Conocybe siliginea (Fr.) Kühner & Thalictro-Salvietum pratensis \\
\hline Crinipellis scabella (Alb. \& Schwein.) Murrill & $\begin{array}{l}\text { Thalictro-Salvietum pratensis, Inuletum ensifoliae, } \\
\text { Origano-Brachypodietum }\end{array}$ \\
\hline Entoloma incanum (Fr.) Hesler & Thalictro-Salvietum pratensis \\
\hline Geastrum minimum Schwein. & Thalictro-Salvietum pratensis \\
\hline Hygrocybe conica (Scop.) P. Kumm. & Thalictro-Salvietum pratensis \\
\hline Hygrocybe insipida (J. E. Lange ex S. Lundell) M. M. Moser & Thalictro-Salvietum pratensis \\
\hline Hygrocybe konradii $\mathrm{R}$. Haller & Origano-Brachypodietum \\
\hline Hygrocybe miniata (Fr.) P. Kumm. & Thalictro-Salvietum pratensis \\
\hline Hygrocybe persistens (Britzelm.) Singer & Thalictro-Salvietum pratensis, Origano-Brachypodietum \\
\hline Hygrocybe reae (Maire) J. E. Lange & Thalictro-Salvietum pratensis \\
\hline Leucopaxillus lepistoides (Maire) Singer & Thalictro-Salvietum pratensis \\
\hline Lepiota alba (Bres.) Sacc. & Thalictro-Salvietum pratensis, Origano-Brachypodietum \\
\hline Lepista personata (Fr.) Cooke & Thalictro-Salvietum pratensis \\
\hline Suillus collinitus (Fr.) Kuntze & Thalictro-Salvietum pratensis, Origano-Brachypodietum \\
\hline Tulostoma fimbriatum $\mathrm{Fr}$. & Thalictro-Salvietum pratensis \\
\hline Vascellum pratense (Pers.) Kreisel & $\begin{array}{l}\text { Thalictro-Salvietum pratensis, Inuletum ensifoliae, } \\
\text { Origano-Brachypodietum }\end{array}$ \\
\hline Morchella esculenta (L.) Pers. & Thalictro-Salvietum pratensis, Origano-Brachypodietum \\
\hline
\end{tabular}

Table 2.

List of rare and threatened macromycetes species of the Chęciny district xerothermic grasslands

\begin{tabular}{lc}
\hline \multicolumn{1}{c}{ Species } & Categories of threat \\
\hline Arrhenia retiruga (Bull.) Redhead & $\mathrm{E}$ \\
Geastrum minimum Schwein. & \\
Hygrocybe insipida (J. E. Lange ex S. Lundell) M. M. Moser & \\
Hygrocybe reae (Maire) J. E. Lange & $\mathrm{V}$ \\
Omphaliaster asterosporus (J. E. Lange) Lamoure & \\
\hline Lepiota alba (Bres.) Sacc. & $\mathrm{R}$ \\
Tricholoma orirubens Quél. & \\
Tulostoma fimbriatum Fr. & \\
\hline Camarophyllus russocoriaceus (Berk. \& Jos. K. Mill.) J. E. Lange & \\
Hygrocybe persistens (Britzelm.) Singer & \\
Morchella esculenta (L.) Pers. &
\end{tabular}


In the grasslands of the Chęciny district, there are also interesting macromycetes species considered to be rare and threatened (Table 2). The study found the occurrence of 11 fungi being on the Polish Red List of Threatened Species (Wojew od a and Ławrynowicz, 2006), with 5 species belonging to category $\mathrm{E}$ (Endangered) and 3 species in each category V and R (Vulnerable and Rare).

Legally protected macromycetes species are a very important group of threatened mycobiota. During the course of the study, 4 fully protected species were found which are as follows: Morchella esculenta, Geastrum minimum, Langermannia gigantea, and Tulostoma fimbriatum.

The habitats of the Chęciny district xerothermic grasslands are the place of occurrence of many interesting macromycetes species, some of which are considered as rare and threatened both in Poland and Europe. In a natural manner, they increase the wealth of habitats and their biocenotic value. The fungi associated with dry and warm habitats are the most interesting. These fungi belong to extremely specialised thermophilous and calciphilous organisms whose development is possible only in deforested and open xerothermic communities. A separate group comprises fungi more often growing in the meadows and pastures, including, among others: Agaricus arvensis, A. pratensis, Cyathus olla, and Camarophyllus virgineus, which also penetrate into xerothermic grasslands enriching their biocenoses.

In the Chęciny district, the main threats for the grasslands and fungi are similar to those existing in other regions of Poland. The factors that destroy plants also destroy macromycetes; for example, grass burning, damage and/or destruction caused in the grasslands by mechanical vehicles, heavy duty cars, motorcycles, and quad bikes also destroy the mycelium. The effective protection of many plant species and macromycetes is only possible by protecting their entire natural habitats, and not only their single components.

The achieved results have a significant importance for the identification of macromycetes biota growing in rare and dying ecosystems in the communities belonging to the class Festuco-Brometea within the investigated area. The knowledge of selected fungi, which can be considered to have diagnostic features, allows us to use these organisms for bioindication and valorisation of their habitats and biocenoses. This is of particularly great significance during the preparation of conservations plans for nature reserves and scientific opinions on environmental issues as well as during the evaluation of negative impacts on the environment when planning investment projects.

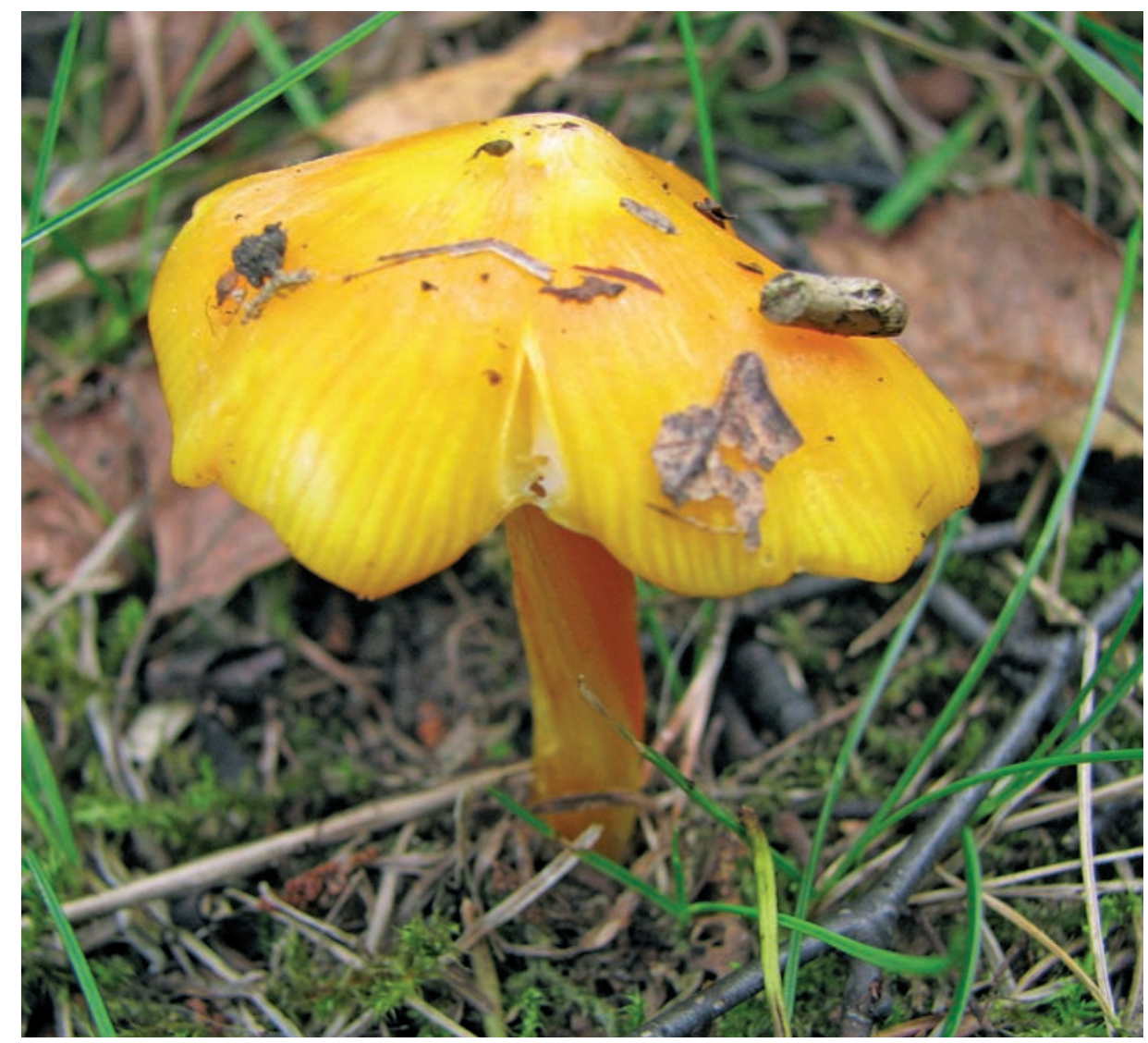

Fig. 1. Fruit body of Hygrocybe konradii at the site in Polichno (1 September 2006; photo by J. Jaworska) 


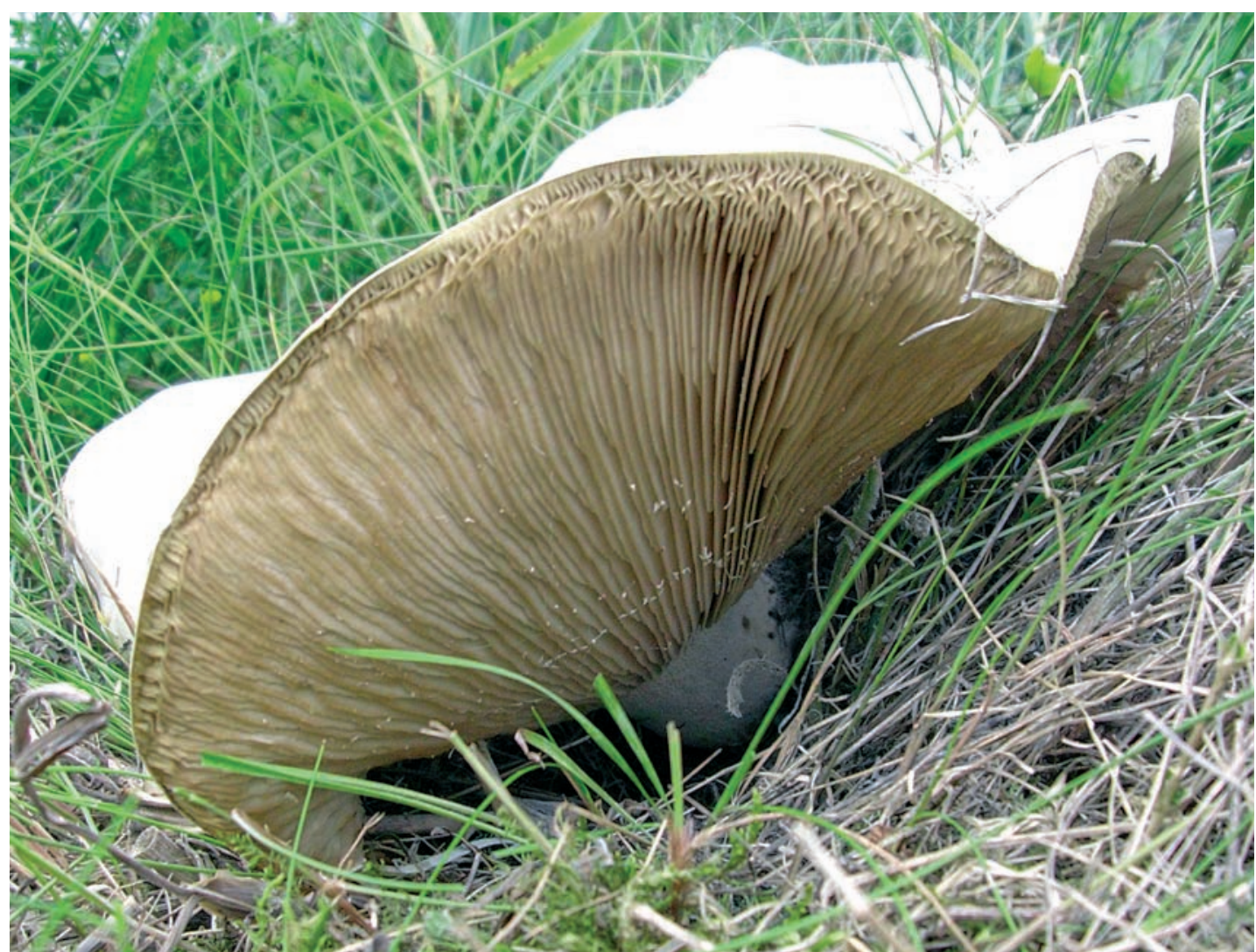

Fig. 2. Fruit body of Leucopaxillus lepistoides at the site in Polichno (27 June 2005; photo by J. Jaworska)

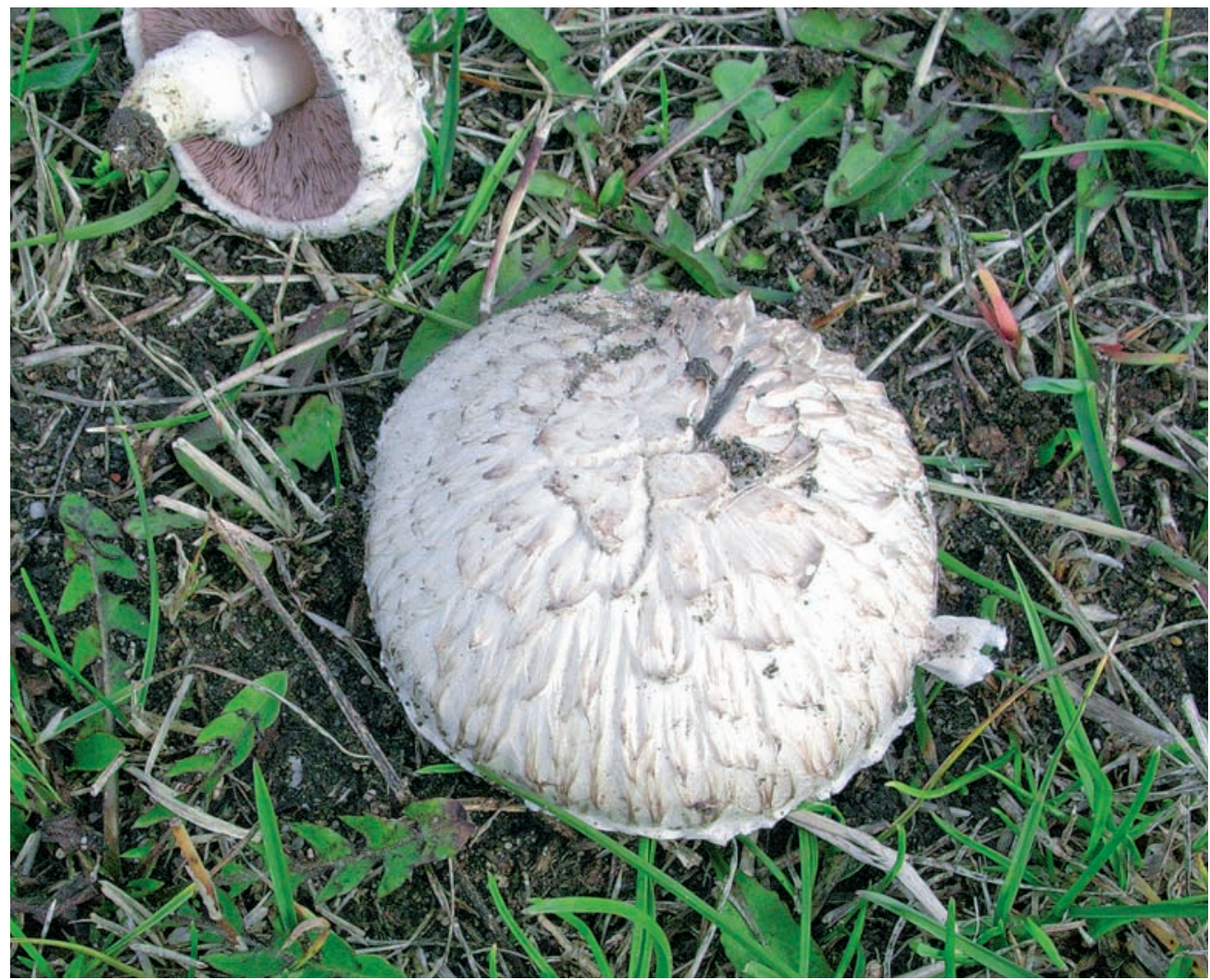

Fig. 3. Fruit body of Agaricus bernardii at the site in Zajączków (10 October 2004; photo by J. Jaworska) 


\section{Acknowledgements}

This study was supported by the ESF Human Capital Operational Programme, grant no. 6/1/8.2.1./ POKL/ 2009.

\section{REFERENCES}

B ra u - B l a nquet J., 1964. Pflanzensoziologie, Wien-New York.

Bujakiewicz A., 1997. Macromyctes occurring in the Violo odoratae-Ulmetum campestris in the Bielinek Reserve on the Odra river. Acta Mycol. 32(2): 187204.

Chmiel M.A., 2006. Checklist of Polish larger Ascomycetes. Krytyczna lista wielkoowocnikowych grzybów workowych Polski. [In:] Biodiversity of Poland 8. Z. Mirek (ed.) W. Szafer Institute of Botany, Polish Academy of Sciences, Kraków: 152 .

Dahlberg A., Croneborg H. (eds)., 2003. 33 threatened fungi. Complementary and revised information on candidates for listing in Appendix 1 of the Bern Convention. EU DG.

Hinkova C., Stoičev G., 1983. Leucopaxillus lepistoides (Maire) Sing. in Bulgaria. Third Nac. Conf. Bot. C. BAN: 39-42.

Jordal J.B., 2002. Hygrocybe and Cuphophyllus as ecological indicators. IMC 7. Book of Abstracts: 46. The $7^{\text {th }}$ International Mycological Congress, Oslo, 11-17 August 2002.

Krieglsteiner L., 1999 a. Pilze im Naturraum Mainfränkische Platten und ihre Einbindung in die Vegetation. Rosenburger Mykologische Schriften 9(1): 1-464 (in German).

Krieglsteiner L., 1999 b. Pilze im Naturraum Mainfränkische Platten und ihre Einbindung in die Vegetation. Rosenburger Mykologische Schriften 9(2): 465-905 (in German).

Lizoň P., 1995. Macrofungi reported as extinct/missing or threatened with extinction in European Red Data Lists. Fungi and Conservation Newsletter 3, September 1995.

Ławrynowicz M., Bujakiewicz A., Mułenko W., 2004. Mycocoenological studies in Poland. 19522002. Monogr. Bot. 93: 1-102.

Łu s zczyńs k i J., 2006. Leucopaxillus lepistoides - a new steppe fungus in Poland. Acta Mycol. 41(2): 279-284.

Łuszczyński J., 2007. Diversity of Basidiomycetes in various ecosystems in the Góry Świętokrzyskie Mts. Monogr. Bot. 97: 1-218.

Łuszczyński J., 2008. Basidiomycetes of the Góry Świętokrzyskie Mts. A checklist. Wyd. Uniwersytetu Humanistyczno-Przyrodniczego Jana Kochanowskiego w Kielcach, Kielce: 240 .

Łuszczyński J ., Łuszczyńska B ., 2009. Steppe macromycetes in xerothermic grasslands in Poland. [In:] Grass research. L. Frey (ed.). W. Szafer Institute of Botany, Polish Academy of Sciences, Kraków: 119-127.
Łuszczyński J ., Łuszczyńska B ., 2010. Ciepłolubne i kserotermiczne nieleśne zbiorowiska roślinne. [In:] Monografia Chęcińsko-Kieleckiego Parku Krajobrazowego. A. Świercz (ed.). Wyd. UJK, KTN, Kielce: 172180 (in Polish).

Łuszczyński J ., 2010. Grzyby wielkoowocnikowe. [In:] Monografia Chęcińsko-Kieleckiego Parku Krajobrazowego. A. Świercz (ed.). Wyd. UJK, KTN, Kielce: 198211(in Polish).

Matuszkiewicz W., 2001. Przewodnik do oznaczania zbiorowisk roślinnych Polski. Vademecum Geobotanicum 3. Wyd. Nauk. PWN, Warszawa: 536 (in Polish).

Mirek Z., Piękoś-Mirkowa H., Zając M., 2002. Flowering plants and pteridophytes of Poland - a checklist. [In:] Biodiversity of Poland 1. Z. Mirek (ed.). W. Szafer Institute of Botany, Polish Academy of Sciences, Kraków: 442.

Newton A.C., Davy L.M., Holden E., Silverside A, Watling R., Ward, S.D., 2003. Status, distribution and definition of mycologically important grasslands in Scotland. Biological Conservation, 111: 11-23.

Senn-Irlet B., Heilmann-Clausen J., Genney D., Dahlberg A., 2007. Guidance for Conservation of Macrofungi in Europe. October 2007. Document prepared for The Directorate of Culture and Cultural and Natural Heritage Council of Europe, Strasbourg, 39 pp.

Skirgiełło A., 1976. Materiały do poznania rozmieszczenia geograficznego grzybów wyższych w Europie. V. Acta Mycol. 12: 155-189.

St a sińska M., 2002. Gastrosporium simplex (Fungi, Hymenogastrales), new localities in Pomerania (NW Poland). Pol. Bot. J. 47(1): 71-74.

S ta sińska M., 2003. Różnorodność grzybów (macromycetes) w warunkach naturalnej sukcesji muraw stepowych. [In:] Człowiek i środowisko przyrodnicze Pomorza Zachodniego. I Środowisko biotyczne. S. Rogalska, J. Domagała (eds). Oficyna IN PLUS, Szczecin, 31-34 (in Polish).

Stasińska M., 2008. The state of knowledge of Macromycetes in xerothermic grasslands in Poland. Ann. UMCS, Biologia, 63(1): 71-78.

Stasińska M., Prajs B., 2002. New record of Montagnea arenaria (Fungi, Agaricales) and its distribution in Poland. Pol. Bot. Journ. 47(2): 211-213.

Šmarda J., 1957. Přispevěk k poznání Gasteromycet v Polsce. Acta Soc. Bot. Pol. 24(2): 319-324 (in Czech).

Winterh off W., 1986. Zur Pilzflora der fraenkischen Gipshügel. Jahresmitteilungen der Naturhistorischen Gesellschaft Nuernberg. Nuernberg, 81-85 (in German).

Winterh off W., 1995. Grosspilze in Kalktrockenrasen der südwestdeutschen Tieflagen. Carolinea 53: 251-258 (in German).

Wojewoda W., 1974. Macromycetes Ojcowskiego Parku Narodowego. I. Flora. Acta Mycol. 10(2): 181-265 (in Polish). 
Wojewoda W., 1975. Macromycetes Ojcowskiego Parku Narodowego. II. Charakterystyka socjologiczno-geograficzna. Acta Mycol. 10(2): 163-212 (in Polish).

Wojewoda W., 2003. Checklist of Polish larger Basidiomycetes. [In:] Biodiversity of Poland 7. Z. Mirek (ed.). W. Szafer Institute of Botany, Polish Academy of Sciences, Kraków: 812.

Wojewoda W., Eawrynowicz M., 2006. Red list of the macrofungi in Poland. [In:] Red list of plants and fungi in Poland. Z. Mirek, K. Zarzycki, W. Wojewoda, Z. Szeląg (eds). W. Szafer Institute of Botany, Polish Academy of Sciences, Kraków: 53-70.

\section{Wskaźnikowe gatunki macromycetes dla muraw kserotermicznych Okręgu Chęcińskiego}

\section{Streszczenie}

W Okręgu Chęcińskim murawy kserotermiczne rozwinęły się na odlesionych zboczach wapiennych wzgórz, skib i pagórków. Ich powstanie związane jest ściśle z rolniczą i pasterską gospodarką człowieka. Mu- rawy te należą do klasy Festuco-Brometea i związku Cirsio-Brachypodion. Najbardziej rozpowszechniony na tym terenie jest zespół Thalictro-Salvietum pratensis. Murawy posiadają własną dla nich charakterystyczną biotę grzybów wielkoowocnikowych. Na uwagę zasługują grzyby stepowe, kserotermiczne i ciepłolubne: Agaricus bernardii, Camarophyllus virgineus, Conocybe sienophylla, Entoloma incanum, Hygrocybe konradii, H. persistens, H. reae, Lepiota alba, Leucopaxillus lepistoides.

W związku z postępującym zarastaniem muraw krzewami i drzewami, między innymi Pinus sylvestris, odnotowuje się gatunki grzybów, które towarzyszą temu gatunkowi sosny: Suillus collinitus oraz wytwarzające owocniki podziemne: Rhizopogon obtextus i Rh. roseolus. Do głównych czynników zagrażających murawom kserotermicznym Okręgu Chęcińskiego należą między innymi: zanikanie i dewastacja siedlisk naturalnych, spowodowane często poprzez niewłaściwą gospodarkę człowieka oraz zanieczyszczenie powietrza, wody i gleby. Skuteczna ochrona rzadkich, zagrożonych, a także prawnie chronionych gatunków grzybów możliwa jest tylko poprzez ochronę naturalnych ich siedlisk traktowanych jako całość. 